\title{
Kontaminasi Merkuri (Hg) pada air sungai, air sumur, sedimen dan ikan di Sungai Kuantan, Riau
}

\author{
Mercury (Hg) contamination in river water, well water, sediment and fish in Kuantan River, Riau \\ Dwi Kartika Asih Hasibuan ${ }^{a}$, Etty Riani ${ }^{b}$, Syaiful Anwar ${ }^{c}$ \\ ${ }^{a}$ Program Studi Ilmu Pengelolaan Sumberdaya Alam dan Lingkungan, Sekolah Pascasarjana IPB University, Kampus IPB Darmaga \\ Bogor, 16680, Indonesia [+62 85271201168] \\ ${ }^{\mathrm{b}}$ Departemen Manajemen Sumberdaya Perairan, Fakultas Perikanan dan Ilmu Kelautan, IPB University, Kampus IPB Darmaga Bogor, \\ 16680, Indonesia \\ 'Departemen Ilmu Tanah dan Sumberdaya Lahan, Fakultas Pertanian, IPB University, Kampus IPB Dramaga Bogor, 16680, Indonesia
}

\section{Article Info:}

Received: 16 - 10 - 2020

Accepted: 09 - 12 - 2020

Keywords:

Amalgamation, illegal gold mining, quality standard of pollution

Corresponding Author: Dwi Kartika Asih Hasibuan Program Studi Ilmu Pengelolaan Sumberdaya Alam dan Lingkungan, IPB University; Tel. +6285271201168 Email: dwikartikaasihhasibuan@gmail. com

\section{How to cite (CSE Style $8^{\text {th }}$ Edition):}

Hasibuan DKA, Riani E, Anwar S. 2020. Kontaminasi merkuri (Hg) pada air sungai, air sumur, sedimen dan ikan di Sungai Kuantan, Riau. JPSL 10(4): 679-687. http://dx.doi.org/10.29244/jpsl.10.4.679-687.

\section{PENDAHULUAN}

Provinsi Riau memiliki potensi bahan tambang yang cukup besar namun belum dikelola dengan baik. Menurut Dinas Energi dan Sumber Daya Mineral Kabupaten Kuantan Singingi, lahan yang mengandung emas alluvial baik di daratan maupun di perbukitan di kabupaten ini \pm 12413.37 ha (Zuhri, 2015). Menurut BPIPDL Kabupaten Kuantan Singingi (2007) Pertambangan Emas Tanpa Ijin (PETI) mulai marak terjadi di kabupaten ini sejak tahun 2006 sampai sekarang. Aktivitas ini telah menimbulkan efek negatif yang sangat meresahkan masyarakat. Sebesar 37.3\% dari total luas wilayah Kabupaten Kuantan Singingi merupakan wilayah aliran Sungai Kuantan, dimana terdapat 10 dari 15 kecamatan yang ada di kabupaten ini dialirin Sungai Kuantan, sepanjang aliran sungai merupakan lokasi pemukiman yang didiami secara turun temurun. Keberadaan PETI 
di Sungai Kuantan berimplikasi terhadap kebiasaan sehari-hari, perilaku sosial ekonomi dan kesehatan masyarakat bantaran sungai (Ayu et al., 2019).

Berdasarkan laporan kualitas air sungai (BPS Kab. Kuantan Singingi, 2016), air sungai di Kabupaten Kuantan Singingi berada di atas kelas II dan hampir mendekati kualitas air untuk kelas III, bahkan ada sungai yang sudah tidak memenuhi baku mutu untuk air sungai kelas IV. Data dari KLHK (2016) menunjukkan secara kimia status sungai masuk dalam kategori tercemar berat, untuk Sungai Kuantan titik tercemar berat berada di Desa Hulu Lubuk Ambacang, Desa Lubuk Jambi, Desa Hilir Pasar Taluk Kuantan dan Kel. Hilir Pasar Urang Baserah. Sejumlah penelitian baik dari kalangan pemerintahan dan akademisi terkait logam merkuri (Hg) selama beberapa dekade ini secara konsisten menemukan bahwa Sungai Kuantan tercemar merkuri (Hg) dalam kategori diambang batas sampai kritis. Berdasarkan informasi tersebut, penelitian ini meninjau kembali secara cermat kontaminasi Hg dari hulu sampai hilir, serta menambah objek teliti seperti, sumur masyarakat, sedimen dan ikan, sehingga lebih mempresentatifkan kondisi terkini terkait kontaminasi Hg.

Menurut Lihawa dan Mahmud (2012) Salah satu dampak negatif yang ditimbulkan akibat PETI dalah pencemaran merkuri dari limbah proses amalgamasi, pada proses ini merkuri dapat terlepas ke lingkungan pada tahap pencucian dan penggarangan. Pada proses pencucian limbah yang umumnya masih mengandung merkuri dalam konsentrasi tinggi dibuang langsung ke badan air. Menurut Agustina (2010), logam-logam tertentu dalam konsentrasi tinggi akan sangat berbahaya bila ditemukan di dalam lingkungan air, tanah dan udara hal ini akan berpengaruh pada kesehatan, baik dalam gangguan saraf, keracunan, kerusakan otak, cacat pada bayi dan keguguran. Dari uraian di atas, penelitian ini penting dilakukan, disebabkan kegiatan PETI sangat berpotensi mengkontaminasi logam berat $\mathrm{Hg}$ ke badan lingkungan dan makhluk hidup. Tujuan penelitian ini adalah untuk mengetahui kandungan merkuri $(\mathrm{Hg})$ pada air sungai, air sumur, sedimen dan ikan di Sungai Kuantan, Riau. Bermanfaat sebagai hasil monitoring lingkungan dan rekomendasi kebijakan pemerintah daerah setempat, terkait penanggulangan pencemaran sungai akibat PETI.

\section{METODE}

\section{Lokasi dan Waktu Penelitian}

Penelitian ini dilaksanakan di Bantaran Sungai Kuantan Kabupaten Kuantan Singingi, Riau sebagai tempat pengambilan sampel. Analisis sampel dilakukan di Laboratorium Teknik Lingkungan Universitas Andalas Padang, Sumatra Barat. Adapun waktu penelitian dilaksanakan selama tiga bulan, yaitu bulan Desember 2019 sampai Februari 2020.

\section{Penentuan Lokasi Sampel}

Lokasi pengambilan sampel ditentukan secara purposive sampling. Pengambilan sampel dilakukan di 3 lokasi yaitu, Kec. Hulu Kuantan (hulu), Kec. Kuantan Tengah (tengah) dan Kec. Kuantan Hilir (hilir), lokasi hulu dan hilir sungai merupakan lokasi yang memiliki intensitas PETI yang cukup tinggi yaitu lokasi hulu berada \pm 50 hingga $100 \mathrm{~m}$ dari lokasi PETI sedangkan lokasi hilir \pm 2 hingga $3 \mathrm{~km}$ dari lokasi PETI. Lokasi tengah sungai berada di ibukota kabupaten, sehingga tidak ada aktivitas PETI di lokasi tersebut. Sampel mencakup air sungai, sedimen, ikan (baung dan kapiek) dan air sumur, lokasi sampel air sumur pada rumah warga ditetapkan pada jarak terdekat dari sungai.

\section{Pengambilan Sampel dan Analisis Kandungan Hg}

Pengambilan sampel air sungai, air sumur dan sedimen dikompositkan agar lebih mewakili. Sampel ikan merupakan dua jenis ikan yang sering dikonsumsi masyarakat (baung dan kapiek), sampel air sumur diambil di dua sumur warga di setiap lokasi pengambilan sampel. Setiap jenis sampel dilakukan pengulangan sebanyak tiga kali. Pengukuran konsentrasi logam berat pada air mengacu pada APHA 2012, 3111-C 22ND edition, sementara pengukuran logam berat pada sedimen dan ikan mengacu pada SNI 06-6992.2-2004. 


\section{Metode Analisis Data}

Penelitian ini menggunakan Rancangan Acak Lengkap (RAL). Hasil analisis logam merkuri dianalisis menggunakan program SPSS 25 dengan uji ANOVA, setelah dilakukan uji normalitas dan homogenitas data untuk memenuhi syarat melakukan uji ini, jika tidak memenuhi syarat maka dilakukan Uji Kruskal Wallis, apabila F diperoleh menunjukkan pengaruh yang nyata (signifikan $<0.05$ ), dilakukan uji lanjut duncan. Hasil analisis dibandingkan dengan standar baku mutu pencemaran.

\section{HASIL DAN PEMBAHASAN}

\section{Air Sungai}

Kandungan Hg pada air Sungai Kuantan pada lokasi hulu, tengah dan hilir adalah sebagai berikut pada Tabel 1. Rata-rata kandungan $\mathrm{Hg}$ di Sungai Kuantan adalah $0.0325 \mathrm{mg} / \mathrm{l}$. Lokasi hulu memiliki rata-rata kandungan $\mathrm{Hg}$ terendah yaitu $0.0230 \mathrm{mg} / \mathrm{l}$, sedangkan lokasi hilir memiliki rata-rata kandungan $\mathrm{Hg}$ tertinggi yaitu $0.0444 \mathrm{mg} / \mathrm{l}$. Hasil perhitungan analisis ragam dari ketiga lokasi Sungai Kuantan menunjukkan adanya perbedaan nyata antara kandungan Hg di setiap lokasi, selanjutnya dilakukan Uji Duncan untuk melihat perbedaan nilai kandungan $\mathrm{Hg}$ pada tiap lokasi Sungai, dari hasil yang didapatkan setiap lokasi memiliki nilai kandungan $\mathrm{Hg}$ signifikan. Rata-rata konsentrasi $\mathrm{Hg}$ secara signifikan naik nilainya dari hulu ke hilir sungai dengan selisih kenaikan $0.007 \mathrm{mg} / \mathrm{l}$ sampai dengan $0.014 \mathrm{mg} / \mathrm{l}$. Merujuk pada standar baku mutu menurut PP No. 82/2001 dan Kepmen LH No. 2/1998, Sungai Kuantan (hulu, tengah, hilir) berada diatas baku mutu pencemaran.

Tabel 1 Rata-rata kosentrasi Hg air sungai

\begin{tabular}{cccc}
\hline No & Lokasi & $\mathrm{Hg}(\mathrm{mg} / \mathrm{l})$ & Std. Deviasi \\
\hline 1 & Hulu & $0.0230^{\mathrm{a}}$ & 0.0014 \\
2 & Tengah & $0.0300^{\mathrm{b}}$ & 0.0009 \\
3 & Hilir & $0.0444^{\mathrm{c}}$ & 0.0017 \\
\hline Rata-rata & & 0.0325 & 0.0094 \\
\hline Baku Mutu $: 0.001 \mathrm{mg} / \mathbf{l}^{*}$ & & &
\end{tabular}

Baku Mutu : $0.001 \mathrm{mg} / \mathrm{l}^{*}$

Angka pada kolom yang sama yang diikuti huruf yang sama berarti tidak berbeda nyata hasil uji DMRT ( $\alpha=$ 0.05); *Standar baku mutu menurut PP No. 82/2001; *Kepmen LH No. 2/1998 (golongan A dan B)

Hasil penelitian Rezki et al. (2017) dilaporkan konsentrasi kandungan Hg di Kec. Kuantan Mudik (hulu sungai) sebesar $<2.4 \times 10^{-5} \mathrm{mg} / \mathrm{l}$ berbeda dengan penelitian di tahun yang sama oleh Hastika et al. (2017) dibeberapa lokasi di sungai terdekteksi 9 x 10 $10^{-3} \mathrm{mg} / \mathrm{l}$ dan $\left.7.8 \times 10^{-5} \mathrm{mg} / \mathrm{l}\right)$. Hasil penelitian Yulis (2018) dengan pengambilan sampel pada 3 titik lokasi yaitu hulu, tengah dan hilir sungai kuantan didapatkan hasil $1.3 \times 10^{-2}$ sampai dengan $1.4 \times 10^{-2} \mathrm{mg} / \mathrm{l}$, dengan kondisi $\mathrm{Hg}$ tertinggi berada di hulu sungai.

Dari hasil penelitian ini, terdapat peningkatan konsentrasi $\mathrm{Hg}$ yang cukup tinggi di Sungai Kuantan, yaitu tahun 2018 sampai 2019 konsentrasi Hg di Sungai Kuantan meningkat drastis, yaitu sekitar 0.01 sampai dengan $0.0304 \mathrm{mg} / \mathrm{l}$. Hal ini menunjukkan adanya intensitas PETI yang cukup tinggi dalam setahun terakhir di Sungai Kuantan.

\section{Air Sumur}

Kandungan $\mathrm{Hg}$ pada air sumur warga pada lokasi hulu, tengah dan hilir adalah sebagai berikut pada Tabel 2. Lokasi hulu sungai berada di bawah limit deteksi pengukuran $\mathrm{Hg}$ pada dua sumur warga, yang berjarak \pm 20 sampai 30 meter dari muka sungai. Logam $\mathrm{Hg}$ terdekteksi di sumur warga pada lokasi tengah dan hilir sungai, hal ini diduga karena jarak sumur dan muka sungai yang berdekatan yaitu \pm 3 sampai 5 meter dari muka sungai. Rata-rata kandungan $\mathrm{Hg}$ tertinggi yaitu $0.0406 \mathrm{mg} / \mathrm{l}$ terdapat pada sumur ke dua warga hilir 
sungai, sedangkan sumur warga tengah bantaran Sungai Kuantan terdapat rata-rata kandungan Hg sebesar 0.0255 sampai dengan $0.0287 \mathrm{mg} / \mathrm{l}$.

Tabel 2 Rata-rata konsentrasi Hg air sumur

\begin{tabular}{cccccc}
\hline No & Lokasi & $\begin{array}{c}\text { Sumur 1 } \\
(\mathrm{mg} / \mathrm{l})\end{array}$ & $\begin{array}{c}\text { Sumur 2 } \\
(\mathrm{mg} / \mathrm{l})\end{array}$ & $\begin{array}{c}\text { Std. Deviasi } \\
\text { Sumur 1 }\end{array}$ & $\begin{array}{c}\text { Std. Deviasi } \\
\text { Sumur 2 }\end{array}$ \\
\hline 1 & Hulu & $0.0001^{\mathrm{a}}$ & $0.0001^{\mathrm{a}}$ & 0.0001 & 0.0001 \\
2 & Tengah & $0.0255^{\mathrm{b}}$ & $0.0287^{\mathrm{b}}$ & 0.0008 & 0.0019 \\
3 & Hilir & $0.0350^{\mathrm{c}}$ & $0.0406^{\mathrm{c}}$ & 0.0008 & 0.0056 \\
\hline Rata-rata & & 0.0202 & 0.0231 & 0.0157 & 0.0183 \\
\hline
\end{tabular}

Baku Mutu: $0.01 \mathrm{mg} / \mathrm{l}^{*} ; 0.001 \mathrm{mg} / \mathrm{l}^{* *}$

Angka pada kolom yang sama yang diikuti huruf yang sama berarti tidak berbeda nyata hasil uji DMRT $(\alpha=$ 0.05); *Permenkes No. 492/2010 (Kualitas Air Minum); **Permenkes No. 32/2017 (standar baku mutu air bersih)

Hasil analisis ragam kandungan $\mathrm{Hg}$ pada dua sumur warga bantaran sungai adalah berbeda nyata (signifikan) di tiap lokasi sungai, dari uji lanjutan duncan didapatkan hasil, setiap lokasi hulu, tengah dan hilir sungai memiliki nilai $\mathrm{Hg}$ yang berbeda nyata. Selisih rata-rata konsentrasi $\mathrm{Hg}$ pada sumur warga hilir dan tengah sebesar 0.0095 sampai dengan $0.0119 \mathrm{mg} / \mathrm{l}$, perbedaan konsentrasi yang signifikan diduga karena limpasan air sungai yang meluap, dikarenakan pengambilan sampel dilakukan pada musim penghujan, jarak sumur yang dekat dengan sungai, juga menjadi penyebab sumur menampung air limpasan tersebut. Standar baku mutu Permenkes No. 32/2017 dan kualitas air minum Permenkes No. 492/2010, menunjukkan bahwa air sumur warga tengah dan hilir sungai diatas baku mutu yang ditetapkan. Hal ini sangat memprihatinkan karena warga masih menggunakan air sumur sebagai kebutuhan dasar sehari-hari, salah satunya mengonsumsi air sumur sebagai air minum.

Belum ditemukan penelitian terkait kandungan $\mathrm{Hg}$, pada sumur warga masyarakat bantaran Sungai Kuantan. Pada Sungai Singingi, yang juga merupakan sungai besar di Kabupaten Kuantan Singingi, menurut penelitian Annisa (2019), berdasarkan hasil uji laboratorium yang telah dilakukan oleh peneliti pada 5 sampel, ditemukan 1 sampel air sumur dengan jarak 10 m dari air sungai dengan kosentrasi $\mathrm{Hg} 1.3$ x $10^{-3} \mathrm{mg} / \mathrm{l}$, yang digunakan masyarakat untuk kebutuhan minum sehari-hari tidak layak digunakan karena, melewati nilai baku mutu yang telah ditetapkan sedangkan untuk 4 sampel air sumur dengan jarak 12, 14, 15 dan 17 meter dari air sungai yang tercemar tidak menunjukkan adanya kandungan merkuri.

Kualitas air tanah secara alami sangat dipengaruhi oleh jenis litologi penyusunan akuifer (unsur-unsur kimia yang ada dalam air tanah terjadi karena adanya interaksi antara air tanah yang bersifat pelarut unsur kimia yang ada dalam batuan penyimpan air tanah), jenis tanah atau batuan yang dilalui air tanah, serta jenis air asal air tanah. Kualitas tersebut akan berubah saat terjadi tindakan-tindakan oleh manusia terhadap air tanah seperti pengambilan air tanah yang berlebihan dan pembuangan limbah (Sudarmadji, 2016; Sudadi, 2003).

Penurunan kualitas air tanah pada sumur masyarakat yang berjarak \pm 3 sampai dengan 5 meter dari air sungai, terbukti mengandung Hg yang melewati nilai ambang batas, hal ini disebabkan karena kegiatan PETI yang masih marak terjadi di lokasi tersebut, selain itu penurunan kualitas air tanah juga dapat terjadi karena jenis tanah pada sumur tersebut. Berdasarkan data geologi Kabupaten Kuantan Singingi jenis tanah yang ada di wilayah Kabupaten adalah jenis tanah alluvial. Tanah alluvial inimerupakan jenis tanah yang terbentuk dari lumpur sungai yang mengendap di dataran rendah yang memiliki sifat tanah yang subur karena kandungan unsur hara yang tinggi. Tanah alluvial memiliki struktur tanah yang tergolong liat atau liat berpasir dengan kandungan pasir kurang dari 50\%. Penurunan kualitas air tanah pada sumur masyarakat ini terjadi karena jaraknya yang dekat dengan air sungai yang tercemar (BPS Kab. Kuantan Singingi, 2014). 


\section{Sedimen}

Kandungan $\mathrm{Hg}$ pada sedimen pada lokasi hulu, tengah dan hilir adalah sebagai berikut pada Tabel 3. Ratarata kandungan $\mathrm{Hg}$ tertinggi terdapat pada sedimen hilir sungai yaitu $0.2378 \mathrm{mg} / \mathrm{kg}$ dan rata-rata konsentrasi terendah terdapat di hulu sungai yaitu $0.1730 \mathrm{mg} / \mathrm{kg}$. Hasil analisis ragam menunjukkan adanya perbedaan nyata antara nilai $\mathrm{Hg}$ pada setiap sedimen di lokasi sungai, dari uji lanjutan duncan didapatkan hasil, setiap lokasi sungai memiliki perbedaan nyata (signifikan) terhadap rata-rata konsentrasi $\mathrm{Hg}$ sedimen. Selisih antara rata-rata konsentrasi Hg sebesar $0.0236 \mathrm{mg} / \mathrm{kg}$ sampai dengan $0.0648 \mathrm{mg} / \mathrm{kg}$. Berdasarkan baku mutu US EPA (1997) sedimen yang terdapat di hulu sungai masih berada di bawah baku mutu yang ditetapkan, sedangkan lokasi tengah dan hilir sungai berada di atas baku mutu yang ditetapkan, sedangkan menurut baku mutu ANZECC/ARMCANZ (2000) dan CCME (2002) ketiga lokasi Sungai Kuantan berada di atas baku mutu yang ditetapkan.

Tabel 3 Rata-rata konsentrasi Hg sedimen

\begin{tabular}{cccc}
\hline No & Lokasi & $\mathrm{Hg}(\mathrm{mg} / \mathrm{kg})$ & Std. Deviasi \\
\hline 1 & Hulu & $0.1730^{\mathrm{a}}$ & 0.0022 \\
2 & Tengah & $0.2142^{\mathrm{b}}$ & 0.0029 \\
3 & Hilir & $0.2378^{\mathrm{c}}$ & 0.0030 \\
\hline Rata-rata & & 0.2083 & 0.0285 \\
\hline
\end{tabular}

Baku mutu (mg/kg): 0.2*; 0.15**; 0.13***

Angka pada kolom yang sama yang diikuti huruf yang sama berarti tidak berbeda nyata hasil uji DMRT $(\alpha=$ 0.05); *US EPA (1997); **ANZECC/ARMCANZ 2000-Low (2000); ***CCME 2002-ISQG (2002)

Masuknya logam berat ke dalam lingkungan perairan akan berdampak pada menurunnnya kualitas lingkungan perairan (Zhang et al., 2009; Riani, 2012). Logam berat pada konsentrasi tertentu dalam perairan akan terakumulasi ke dalam sedimen (Rochyatun et al., 2006; Edu et al., 2015) dan pada organisme perairan (Wulandari et al., 2012; Riani et al., 2014).

Kontaminasi merkuri di sedimen terjadi karena proses alamiah (pelapukan batuan termineralisasi), proses pengolahan emas secara tradisional (amalgamasi), maupun proses industri yang menggunakan bahan baku yang mengandung merkuri. Nilai anomali unsur $\mathrm{Hg}$ dalam sedimen harus di evaluasi secara hati-hati mengingat besar kemungkinan terjadi pencemaran akibat pemakaian merkuri oleh pertambangan emas tanpa izin (PETI). Kontur dasar berbatu biasanya tidak mengalami mineralisasi. Konsentrasi merkuri sangat berhubungan erat dengan pemakaian merkuri dalam proses amalgamasi (Widhiyatna et al., 2005).

Logam berat menjadi perhatian khusus karena keberadaannya di lingkungan mengalami daur ulang biogeokimia, dan resiko ekologis. Ketika terjadi resuspensi sedimen, banyak logam, termasuk terlarut dan fraksi partikel, yang dilepaskan ke dalam kolom air. Organisme akuatik mengasimilasi logam terlarut dengan mudah, menyebabkan bioakumulasi. Proses resuspensi, partikulat logam secara bertahap menetap pada sedimen dan kemudian diserap oleh hydrophytes dan zoobenthos (Ip et al., 2005).

\section{Ikan Baung dan Ikan Kapiek}

Kandungan Hg pada ikan baung dan ikan kapiek pada lokasi hulu, tengah dan hilir adalah sebagai berikut pada Tabel 4. Kandungan Hg tertinggi terdapat pada ikan baung yang ditangkap di lokasi hilir sungai sebesar $0.1239 \mathrm{mg} / \mathrm{kg}$ dan yang paling rendah sebesar $0.1076 \mathrm{mg} / \mathrm{kg}$ pada ikan baung yang ditangkap di lokasi tengah sungai. Berdasarkan hasil analisis ragam, tidak terdapat adanya perbedaan nyata antara konsentrasi Hg pada setiap lokasi hasil tangkap ikan baung. 
Tabel 4 Rata-rata konsentrasi Hg ikan

\begin{tabular}{cccccc}
\hline No & Lokasi & $\begin{array}{c}\text { Baung } \\
(\mathrm{mg} / \mathrm{kg})\end{array}$ & $\begin{array}{c}\text { Kapiek } \\
(\mathrm{mg} / \mathrm{kg})\end{array}$ & $\begin{array}{c}\text { Std. Deviasi } \\
\text { Baung }\end{array}$ & $\begin{array}{c}\text { Std. Deviasi } \\
\text { Kapiek }\end{array}$ \\
\hline 1 & Hulu & $0.1107^{\mathrm{a}}$ & $0.1234^{\mathrm{b}}$ & 0.0012 & 0.0005 \\
2 & Tengah & $0.1076^{\mathrm{a}}$ & $0.1172^{\mathrm{a}}$ & 0.0031 & 0.0023 \\
3 & Hilir & $0.1239^{\mathrm{a}}$ & $0.1266^{\mathrm{b}}$ & 0.0024 & 0.0022 \\
\hline \multicolumn{2}{l}{ Rata-rata } & 0.1141 & 0.1224 & 0.0078 & 0.0045 \\
\hline \multicolumn{2}{l}{ Baku mutu $: 0.5 \mathrm{mg} / \mathrm{kg}^{*}$} & & & \\
\hline
\end{tabular}

Angka pada kolom yang sama yang diikuti huruf yang sama berarti tidak berbeda nyata hasil uji DMRT $(\alpha=$ 0.05); *PBPOM No.5/2018 (batas maksimum cemaran logam berat dalam pangan olahan) dan SNI 7387:2009

Kandungan $\mathrm{Hg}$ pada ikan kapiek tertinggi ditangkap di lokasi hilir sungai sebesar $0.1266 \mathrm{mg} / \mathrm{kg}$ dan yang paling rendah sebesar $0.1172 \mathrm{mg} / \mathrm{kg}$ pada ikan kapiek yang ditangkap di lokasi tengah sungai. Berdasarkan hasil analisis ragam, terdapat adanya perbedaan nyata antara konsentrasi $\mathrm{Hg}$ pada setiap lokasi hasil tangkap ikan kapiek. Uji lanjutan duncan didapatkan hasil, ikan kapiek di lokasi tengah sungai memiliki perbedaan nyata (signifikan), sedangkan di lokasi hulu dan hilir sungai, tidak ada perbedaan nyata (tidak signifikan) terhadap konsentrasi Hg, namun demikian merujuk pada baku mutu PBPOM No.5/2018 dan SNI 7387:2009 tentang batas maksimum cemaran logam berat dalam pangan olahan, ikan baung dan ikan kapiek Sungai Kuantan masih berada di bawah baku mutu yang ditetapkan.

Secara spesifik perairan Sungai Kuantan ini sangat sesuai untuk perkembangbiakan ikan, ini dapat dibuktikan dengan banyaknya jenis ikan yang melakukan pemijahan di perairan ini khususnya ikan patin, baung dan lain-lain yang mempunyai nilai ekonomis tinggi (Johan dan ediwarman, 2011). Banyaknya Rumah Tangga Perikanan (RTP) pada sungai di Kabupaten Kuantan Singingi tahun 2015 sampai dengan 2019 adalah 1461 sampai dengan 1901 KK (Kepala Keluarga), dengan sungai sebagai jenis perairan tangkap yang tertinggi, diantara danau, bendungan dan rawa-rawa. Hal ini menunjukkan masyarakat masih menjadikan sungai sebagai penangkapan/budidaya ikan dengan tujuan peningkatan ekonomi keluarga (BPS Kab. Kuantan Singingi, 2019). Ikan baung dan kapiek juga merupakan, ikan yang banyak dijadikan olahan utama sebagai makanan tradisional masyarakat melayu Riau, untuk di daerah bantaran Sungai Kuantan sendiri, setelah dilakukan wawancara masyarakat, terkait pola konsumsi, dua jenis ikan ini termasuk sebagai jenis ikan, yang paling banyak dikonsumsi masyarakat bantaran sungai.

Taftazani (2004) menjelaskan bahwa proses transformasi merkuri dalam sistem rantai makanan mengalami pelipatgandaan (bioakumulasi). Konsentrasi merkuri yang masuk dan terakumulasi dalam jaringan biota terus meningkat seiring dengan peningkatan strata atau posisi dari biota tersebut dalam sistem rantai makanan yang dikenal dengan biomagnifikasi. Sehingga biota seperti ikan-ikan besar yang telah memakan ikan-ikan yang lebih kecil yang telah terkontaminasi oleh merkuri, disinyalir mempunyai kandungan merkuri yang lebih besar dalam tubuhnya dan manusia yang menempati posisi puncak dari sistem rantai makanan akan mengakumulasi merkuri dalam jumlah yang lebih tinggi (McIntyre dan Beauchamp, 2007). Selain itu, akumulasi merkuri dalam biota terpusat pada organ tubuh yang berfungsi untuk reproduksi, sehingga akan berpengaruh terhadap perkembangan kehidupan biota tersebut. Disamping itu merkuri yang diakumulasi dalam tubuh biota akan merangsang sistem enzimatik, yang dapat menurunkan kemampuan adaptasi pada lingkungan tercemar.

Kegiatan antropogenik melepaskan logam berat di udara, tanah, dan air, sehingga mengekspos biota, yang berpotensi membahayakan. Sistem alam dapat bertindak sebagai filter yang efektif dengan mempertahankan senyawa beracun dalam tanah atau mungkin mentransfernya ke ekosistem darat dan air, sehingga meningkatkan bioavailabilitas dengan demikian dapat menimbulkan risiko keracunan biota dan manusia (Sanchez-Chardi et al., 2007). 


\section{KESIMPULAN}

Simpulan dari penelitian ini adalah konsentrasi Hg pada air sungai, air sumur (tengah dan hilir), sedimen berada di atas baku mutu pencemaran, sedangkan pada sampel ikan baung dan ikan kapiek, masih berada di bawah standar baku mutu pencemaran. Konsentrasi $\mathrm{Hg}$ secara signifikan meningkat dari lokasi hulu sampai hilir pada air sungai dan sedimen, konsentrasi Hg secara signifikan meningkat pada dua sumur warga di lokasi tengah dan hilir, konsentrasi $\mathrm{Hg}$ secara signifikan terdapat pada ikan kapiek yang ditangkap di lokasi tengah sungai dan tidak ada perbedaan nyata pada konsentrasi Hg ikan baung di lokasi penelitian.

Saran dari penelitian ini adalah, perlu dilakukan penertiban PETI secara masif, kolaboratif dan berintegritas tinggi, serta melakukan penyuluhan dan pembinaan masyarakat bantaran sungai. Dapat dilakukan penelitian lanjutan untuk mengetahui dampak akibat kontaminasi logam berat $\mathrm{Hg}$ pada masyarakat bantaran Sungai Kuantan.

\section{DAFTAR PUSTAKA}

[ANZECC/ARMCANZ] Australian and New Zealand Environment and Conservation Council and Agriculture and Resource Management Council of Australia and New Zealand. 2000. Australian And New Zealand Guidelines For Fresh And Marine Water Quality Volume 1. Canberra (AU): Australian and New Zealand Environment and Conservation Council. hlm 256-257.

[BPIPDL] Badan Promosi Investasi dan Pengendalian Dampak Lingkungan Kabupaten Kuantan Singingi. 2007. Laporan Status Lingkungan Hidup Daerah Kabupaten Kuantan Singingi Tahun 2007. Riau (ID): Kabupaten Kuantan Singingi Pr. hlm 56-69.

[BPS Kab. Kuantan Singingi] Badan Pusat Statistik Kabupaten Kuantan Singingi. 2014. Profil Kabupaten Kuantan Singingi 2014 [Internet]. [diunduh 2019 Sep 28]. Tersedia pada: http://sippa.ciptakarya.pu.go.id/sippa_online/ws_file/dokumen/rpi2jm/DOCRPI_1507843209RPI2JM _kuansing_BAB_4_Profil_Kab_Kota,_cek_data_2012,_dan_1_uas_wilayah_peranap.pdf.

[BPS Kab. Kuantan Singingi] Badan Pusat Statistik Kabupaten Kuantan Singingi. 2016. Laporan Kualitas Air Sungai Kabupaten Kuantan Singingi 2016 [internet]. [diakses 2019 Sep 17]. Tersedia pada: https://sirusa.bps.go.id/sirusa/index.php/sektoral/pdf?kd=9942\&th=2016.

[BPS Kab. Kuantan Singingi] Badan Pusat Statistik Kabupaten Kuantan Singingi. 2019. Profil Kabupaten Kuantan Singingi 2019 [Internet]. [diunduh 2019 Sep 28]. Tersedia pada: https://kuansingkab.bps.go.id/publication/2019/08/16/3d9839f19569a9499531404d/kabupatenkuantan-singingi-dalam-angka-2019.html.

[BSN] Badan Standardisasi Nasional. 2009. SNI 06-6992.2-2004. Jakarta (ID): BSN.

[BSN] Badan Standardisasi Nasional. 2009. Standar Nasional Indonesia 7387:2009: Batas Maksimum Cemaran Logam Berat Pada Pangan [Internet]. Jakarta (ID): BSN. [diakses 2020 Sep 29]. Tersedia pada: https://sertifikasibbia.com/upload/logam_berat.pdf.

[CCME] Canadian Council of Ministers of the Environment. 2002. Canadian Sediment Quality Guidelines For The Protection Of Aquatic Life. Canada (US): Canadian Environmental Quality Guidelines.

[Kemeneg KLH] Kementerian Negara Kependudukan dan Lingkungan Hidup. 1988. Keputusan Kementerian Negara Kependudukan dan Lingkungan Hidup (Kepmen LH) Nomor: KEP-02/MENKLH/1988 tentang Pedoman Penetapan Baku Mutu Lingkungan Hidup [Internet]. [diakses 2020 Sep 22]. Tersedia pada: https://indok31l.com/keputusan-menteri-negara-kependudukan-dan-lingkungan-hidup-nomor-kep-02menklh-i-1988/.

[KLHK] Direktorak Jendral Pengendalian Pencemaran dan Kerusakan Lingkungan Kementerian Lingkungan Hidup dan Kehutanan. 2016. Atlas Status Mutu Air Indonesia Tahun 2016. Jakarta (ID): KLHK Pr. 
[PBPOM] Peraturan Badan Pengawasan Obat dan Makanan Nomor 5 Tahun 2018. Batas Maksimum Cemaran Logam Berat dalam Pangan Olahan [Internet]. [diakses 2020 Sep 22]. Tersedia pada: file://C:/Users/User/AppData/Local/Temp/0.\%20salinan\%20PerBPOM\%205\%20Tahun\%202018\%2 0Cemaran\%20Logam\%20Berat\%20join.pdf.

[PERMENKES] Peraturan Menteri Kesehatan Republik Indonesia Nomor 492/MENKES/PER/IV/2010. 2010. Persyaratan Kualitas Air Minum [Internet]. [diakses 2020 Sep 22]. Tersedia pada: https://www.slideshare.net/metrosanita/permenkes-492-tahun-2010-tentang-persyaratan-kualitas-airminum.

[PERMENKES] Peratutan Menteri Kesehatan Republik Indonesia Nomor 32 Tahun 2017. 2017. Standar Baku Mutu Kesehatan Lingkungan dan Persyaratan Kesehatan air untuk Keperluan Higiene Sanitasi, Kolam Renang, Solus Per Aqua dan Pemandian Umum [Internet]. [diakses 2020 Sep 22]. Tersedia pada: http://hukor.kemkes.go.id/uploads/produk_hukum/PMK_No._32_ttg_Standar_Baku_Mutu_Kesehatan _Air_Keperluan_Sanitasi,_Kolam_Renang,_Solus_Per_Aqua_.pdf

[US EPA] United States Enviromental Protect Agency. 1997. Mercury Study Report to Congress, Office of Air Quality Planning and Standards and Office of Research and Development. Washington DC (US): Environmental Protection Agency.

Agustina T. 2010. Kontaminasi logam berat pada makanan dan dampaknya pada kesehatan. J Teknubuga. 2(2): 53-65.

Annisa K. 2019. Analisis paparan merkuri dengan keluhan kesehatan pada masyarakat di sekitar kawasan pertambangan emas tradisional Kelurahan Muara Lembu Riau Tahun 2019 [skripsi]. Medan (ID): Universitas Sumatra Utara.

Ayu AP, Agustar A, Syarfi IW. 2019. Karakteristik sosial ekonomi masyarakat di sepanjang aliran sungai kuantan kabupaten kuantan singingi dan implikasinya pada kebijakan dan pelaksanaan pembangunan. JISPO. 9(2): 159-173.

Edu EAB, Edwin-Wosu NL, Inegbedion A. 2015. Bio-monitoring of mangal sediments and tissues for heavy metal accumulation in the mangrove forest of cross River Estuary. Insight Ecology. 4(1): 46-52.

Hastika RG, Indang D, Alizar, Purwo S, Saiful A. 2017. Determination of mercury (Hg) on water sample in Batang Kuantan river. International coference of applied science on enginineering, business, linguistic and information technology (Ico-ASCNITech) [Internet]. hal 305-308. [diakses 2020 Sep 22]. Tersedia pada: https://osf.io/preprints/inarxiv/8ysm2/.

Ip CCM, Li XD, Zhang G, Wong CSC, Zhang WL. 2005. Heavy metal and Pb isotopic compositions of aquatic organisms in the Pearl River Estuary, South China. Environmental Pollution. 138(3): 494-504.

Johan T, Ediwarman. 2011. Dampak penambangan emas terhadap kualitas air sungai singingi di Kabupaten Kuantan Singingi Provinsi Riau. J Ilmu Lingkungan. 5(2): 168-183.

Lihawa F, Mahmud M. 2012. Sebaran spasial dan temporal kandungan merkuri pada lokasi pertambangan emas tradisional di Kabupaten Bone Bolango. Laporan Hasil Penelitian. Gorontalo (ID): Pusat Studi Lingkungan Hidup Universitas Gorontalo.

McIntyre JK, Beauchamp DA. 2007. Age and trophic position dominate bioaccumulation of mercury and organochlorines in the food web of Lake Washington. Science Total Environment. 372(2-3): 571-584.

Pemerintah Indonesia. 2001. Peraturan Pemerintah (PP) Republik Indonesia Nomor 82 Tahun 2001 tentang Pengelolaan Kualitas Air dan Pengendalian Pencemaran Air [Internet]. [diakses 2020 Sep 22]. Tersedia pada: https://peraturan.bpk.go.id/Home/Details/53103/pp-no-82-tahun-2011.

Rezki M, Zulkarnaini, Sofia A. 2017. Kajian dampak penambangan emas tanpa izin (PETI) terhadap lingkungan Sungai Batang Kuantan Kecamatan Kuantan Mudik Kabupaten Kuantan Singingi Riau. J Lingkungan. 11(2): 106-115.

Riani E. 2012. Perubahan Iklim dan Kehidupan Biota Akuatik (Dampak pada Bioakumulasi Bahan Berbahaya dan Beracun \& Reproduksi). Bogor (ID): IPB Press. 
Riani E, Sudarso Y, Cordova MR, 2014. Heavy metals effect on unviable larvae of Dicrotendipes simpsoni (Diptera: Chironomidae), a case study from Saguling Dam, Indonesia. Aquaculture, Aquarium, Concervation and Legislation International Journal of the Bioflux Society. 7(2): 76-84.

Rochyatun E, Kaisupy MT, Rozak A. 2006. Distribusi logam berat dalam air dan sedimen di perairan muara Sungai Cisadane. Makara Sains. 10(1): 35-40.

Sanchez-Chardi A, Penarroja-Matutano C, Oliveira Ribeiro CA. Nadal, J. 2007. Bioaccumulation of metals and effects of a landfill in small mammals. Part II. The wood mouse. Apodemus sylvaticus Chemical. 70(1): 101-109.

Sudadi P. 2003. Penentuan Kualitas air tanah melalui analisis unsur kimia terpilih. Buletin Geologi Tata Lingkungan. 13(2): 81-89.

Sudarmadji. 2016. Pengelolaan Sumberdaya Air Terpadu (Edisi ke-1). Yogyakarta (ID): Gadjah Mada University Press. hlm 56-69.

Taftazani A. 2004. Distribusi Konsentrasi Logam Berat Hg Dan Cr Pada Sampel Lingkungan Perairan Surabaya. Prosiding PPI-PDIPTN Pustek Akselerator dan Proses Bahan. Yogyakarta (ID): PTAPBBATAN. hlm 36-45.

Widhiyatna D, Tjahjono B, Gunrady R, Sukandar MM, Ta'in Z. 2005. Pendataan Sebaran Merkuri Di daerah Cineam, Kabupaten Tasikmalaya, Jawa Barat dan Sangon, Kabupaten Kulon Progo, Di Yogyakarta. Yogjakarta (ID): Subdit Konservasi. hlm 87-96.

Wulandari EE, Herawati Y, Arfiati D. 2012. Kandungan logam berat Pb pada air laut dan tiram Saccostrea glomerata sebagai bioindikator kualitas perairan Prigi, Trenggalek, Jawa Timur. Jurnal Penelitian Perikanan. 1(1): 10-14.

Yulis PAR. 2018. Analisis kadar logam merkuri $(\mathrm{Hg})$ dan $(\mathrm{pH})$ air Sungai Kuantan terdampak penambangan emas tanpa ijin (PETI). J Pend Kimia. 2(1): 28-31.

Zhang MC, Lijuan L, Sheng Y, Wang. 2009. Distribution and enrichment of heavy metals among sediments, water body and plants in Hengshuihu Wetland of Northern China. Ecological engineering. 35(4): $563-$ 369.

Zuhri A. 2015. Konflik pertambangan emas tanpa ijin (peti) di Desa Petapahan Kecamatan Gunung Toar Kabupaten Kuantan Singing. J FISIP. 2(2): 1-12. 